\title{
HERPES ZOSTER NEONATORUM
}

\author{
BY \\ G. V. FELDMAN \\ From the Department of Child Health, University of Manchester
}

(RECEIVE FOR PUBlication AUgust 9, 1951)

In spite of the widespread occurrence of herpes zoster few cases have been reported in the newborn. As long ago as 1889 Lomer reported its occurrence in an infant aged 4 days and mentioned that a similar case had been reported by Bohn 20 years earlier. Further cases have been reported by Gaehde (1897), Kalb (1909), Bonar and Pearsall (1932), Tausch (1932), Katayama (1938), Freud, Rook and Gurian (1942) and Counter and Korn (1950).

The case described by Kalb (1909) is interesting because of multiple symmetrical scar formation in the distribution of the first and second divisions of the trigeminal nerves which was considered to be due to a possible intra-uterine infection with zoster.

In Katayama's series of 487 cases only one occurred in the newborn, and in a series of 1,406 cases of herpes zoster reviewed by Lang (1938) there were no cases in children under the age of 4 years. Comby (1922) reported 84 cases which had occurred in children under the age of 15 , but the youngest child was 8 months old.

In view of the rarity of herpes zoster in the newborn it was thought worth recording the following case which has the added interesting feature that it occurred in a twin, the other twin being unaffected.

\section{Case Report}

Twin infants were born on April 21, 1951. The first twin, the subject of this report, presented by the breech with extended legs. Delivery was difficult and was effected by fundal pressure, episiotomy and traction to the right groin during five contractions, forceps being applied to the after-coming head. The second twin was delivered as a vertex and was normal. No resuscitation was required and both infants were well.

On the fourth day after delivery a herpetiform eruption of a single line of vesicles the size of a pin-head on an erythematous base appeared on the right thigh and by the fifth day extended from the middle of the right buttock to the middle third of the calf, extending along the course of the sciatic nerve to the lower margin of the popliteal fossa where it divided, and scattered lesions were present on the postero-lateral and posteromedial aspects of the calf. There were no other lesions elsewhere on the body. By the ninth day the original lesions had dried but a few new vesicles appeared on the lower third of the calf. When seen on the twentysecond day only superficial scarring remained. The infant showed no evidence of constitutional upset during the course of the disease and was apparently not in pain.

The course of the pregnancy had been uneventful in the main but the mother stated that she suffered from herpes zoster just before or at the beginning of the pregnancy, though she could not be definite about the exact date. She had had measles and chickenpox during childhood. There was a strong family history of tuberculous infection but the mother herself showed no signs of active infection.

Virus Investigations. Fluid from fresh vesicles taken on the fifth day of life was treated with penicillin and streptomycin and inoculated intracerebrally into adult and sucking mice and onto the chorio-allantois of three 12-day-old chick embryos. The mice remained well and no lesions appeared on the chorio-allantoic membranes. Passage of these membranes to a second batch of eggs produced no herpetic or vaccinial lesions.

A stained smear of vesicle fluid contained bodies of a size similar to elementary bodies of the pox group of viruses but no definite opinion could be given as to their identity.

A further interesting feature is that the obstetrician who delivered the twins developed herpes zoster 14 days later ( 10 days after the development of the eruption on the infant), and the bacteriologist who took scrapings from the lesion for culture also developed herpes zoster, 15 days after contact with the infant.

\section{Discussion}

Trauma is known to precipitate the rash, and this is supported by the case of Bonar and Pearsall (1932) in which traction on the head at delivery, with probable trauma to the brachial plexus. was 


\begin{tabular}{|c|c|c|c|c|c|c|c|}
\hline \multicolumn{2}{|l|}{ Serum } & Date & \multicolumn{4}{|c|}{$\begin{array}{l}\text { C.F.T. with } \\
\text { C.A.M. Antigen }\end{array}$} & $\begin{array}{c}\text { Neutralization in } \\
\text { Virus-serum } \\
\text { Mixtures on } \\
\text { Chorio-allantois } \\
(\%)\end{array}$ \\
\hline $\begin{array}{l}\text { Mother .. .. } \\
\text { Infected twin .. } \\
\text { A.W. (infected twin) } \\
\text { P.W. (normal twin) }\end{array}$ & $\begin{array}{ll} & \\
\ldots & \ldots \\
\cdots & \ldots \\
\ldots & \ldots\end{array}$ & $\begin{array}{l}26.4 .51 \\
26.4 .51 \\
11.5 .51 \\
11.5 .51\end{array}$ & $\begin{array}{l}1 / 12 \\
1 / 12 \\
1 / 3 \\
1 / 3\end{array}$ & $\begin{array}{l}++++ \\
++++ \\
++++ \\
++++\end{array}$ & $\begin{array}{l}1 / 24 \\
1 / 24 \\
1 / 6 \\
1 / 6\end{array}$ & $\begin{array}{l} \pm+ \\
= \\
=\end{array}$ & $\begin{array}{l}99 \cdot 7 \\
99.6 \\
98.8 \\
97.9\end{array}$ \\
\hline
\end{tabular}

- Degree of fixation at serum dilutions stated.

followed by the eruption of herpes zoster on the arm. The cause of the eruption on the course of the right sciatic nerve in the one twin while the other was unaffected may well be explained by the trauma to the right leg from traction on the right groin while the legs were extended during delivery.

In Katayama's (1938) series the sacral distribution of herpes zoster was the rarest, whereas in three reported cases occurring in the newborn, and in the present case, the sacral nerves were involved. Thus it has occurred in four of 10 cases in the newborn as compared with 24 of 487 at other ages collected by Katayama.

The mode of infection in this case is not clear. It is known that the mother had herpes zoster just before, or in the early weeks of, pregnancy, but to her knowledge she had not been in contact with either herpes zoster or chickenpox since then. This suggests that if the infection occurred during the early weeks of the pregnancy the developing foetus became infected before maternal antibodies could be formed, in which case the virus survived in the infant until after birth.

In one of the reported cases serious ill effects were noted, convulsions and death occurring soon after the eruption (Gaehde, 1897). In all other cases, including the present one, the rash appears to have produced little if any constitutional or local upset.

The infant described by Counter and Korn (1950) was subsequently found to be blind but this may not have been related to the herpes zoster.

Although the diagnosis of herpes zoster was not in doubt clinically, it was thought of interest to exclude the possibility of herpes simplex infection. The falling titre in the complement fixation test on the affected infant's serum was against a diagnosis of herpes simplex. The negative culture was also a factor in favour of a diagnosis of zoster and against that of herpes simplex in view of the fact that the herpes virus can be readily isolated in the acute phase of an illness.

\section{Summary}

The literature of herpes zoster in the newborn is reviewed.

A case occurring in one infant of a twin pregnancy is described.

Trauma is a possible factor in precipitating the rash in this instance.

It is suggested that possibly the foetus may have been infected in the early weeks of pregnancy.

My thanks are due to Professor Wilfrid Gaisford for helpful advice and criticism; to Dr. G. M. Komrower for permission to publish the case under his care; to Dr. A. Holzel for translating the literature; to Dr. J. O'H. Tobin for the virus investigations.

\section{REFERENCES}

Bonar, B. E. and Pearsall, C. J. (1932). Amer. J. Dis. Child., 44, 398.

Counter, C. E. and Korn, B. J. (1950). Arch. Pediat., $67,397$.

Comby, J. (1922). Bull. Soc. méd. Hôp. Paris, 46, 992.

Freud, P., Rook, G. D. and Gurian, S. (1942). Amer. J. Dis. Child., 64, 895.

Gaehde, F. (1897). Dtsch. med. Stchr., 101, 1016.

Kalb, O. (1909). Zbl. Gynäk., 33, 929.

Katayama, K. (1938). Jap. J. Derm. Urol., 43, 145.

Lang, J. (1938). Arch. Derm. Syph., Wien, 176, 515.

Lomer, H. (1889). Z Zbl. Gynäk., 13, 778.

Tausch, M. (1932). Ibid., 56, 1629. 